\title{
A Review of Coccidioides Research, Outstanding Questions in the Field, and Contributions by Women Scientists
}

\author{
Morgan E. Gorris ${ }^{1}$ (D) $\cdot$ Marley C. Caballero Van Dyke ${ }^{2}$ (D) $\cdot$ Adrienne Carey $^{3}$ (D) $\cdot$ Paris S. Hamm $^{4}$ (D) $\cdot$ Heather L. Mead $^{2}$ (D) \\ Jessie K. Uehling ${ }^{5}$
}

Accepted: 18 June 2021

(C) The Author(s) 2021

\begin{abstract}
Purpose of Review Coccidioidomycosis is an infectious disease that gained clinical significance in the early 20th century. Many of the foundational contributions to coccidioidomycosis research, including the discovery of the fungal disease agent, Coccidioides spp., were made by women. We review recent progress in Coccidioides research and big questions remaining in the field, while highlighting some of the contributions from women.

Recent Findings New molecular-based techniques provide a promising method for detecting Coccidioides, which can help determine the dominate reservoir host and ideal environmental conditions for growth. Genetic and genomic analyses have allowed an understanding of population structure, species level diversity, and evolutionary histories. We present a current, comprehensive genome list, where women contributed many of these entries. Several efforts to develop a coccidioidomycosis vaccine are underway.

Summary Women continue to pioneer research on Coccidioides, including the relationships between the fungi and the environment, genetics, and clinical observations. Significant questions remain in the field of Coccidioides, including the main host reservoir, the relationships between genotypic and phenotypic variation, and the underlying cause for chronic clinical coccidioidomycosis cases.
\end{abstract}

Keywords Coccidioides $\cdot$ Mycology $\cdot$ Environment $\cdot$ Genetics $\cdot$ Host response $\cdot$ Valley fever

\section{Introduction}

Since the early twentieth century when coccidioidomycosis gained clinical significance, women have made significant

This article is part of the Topical Collection on Mycology

Morgan E. Gorris

mgorris@lanl.gov

1 Los Alamos National Laboratory, Information Systems and Modeling \& Center for Nonlinear Studies, Los Alamos, NM, USA

2 Pathogen and Microbiome Institute, Northern Arizona University, Flagstaff, AZ, USA

3 Division of Infectious Diseases, University of Utah School of Medicine, Salt Lake City, UT, USA

4 Department of Biology, University of New Mexico, Albuquerque, NM, USA

5 Department of Botany and Plant Pathology, Oregon State University, Corvallis, OR, USA contributions to the advancements in understanding this disease. Many of the foundational studies on the environmental, genetic, and clinical aspects of coccidioidomycosis have been led by women, including the identification of the causative fungal pathogen, Coccidioides spp. In 1934, Dr. Myrnie Gifford, an assistant health officer for Kern County, California, was the first physician to investigate a Californian disease called "San Joaquin Valley fever" (the origins of its colloquial name, Valley fever). She proved that Coccidioides was the causative agent for Valley fever and continued to observe clinical and epidemiological outcomes throughout her career [1-4]. This initial connection between the causative agent and resultant Coccidioides infection provided a clear target for future research endeavors and immediately helped raise awareness about the risk for coccidioidomycosis, especially in California's Central Valley.

As the foundational knowledge about Coccidioides continued to grow, women approached the need to understand what communities may be at risk for coccidioidomycosis infection. Starting in the mid-1940s, Dr. Phyllis Edwards, in collaboration with Dr. Caroll Palmer, conducted a seminal 
seroprevalence study among young, healthy volunteers to establish the first Coccidioides endemic map [5]. Conducted between 1945 and 1951, over 110,000 Navy recruits, student nurses, and college students were enrolled in this coccidioidin skin testing study that led to the first known map of disease distribution across the USA. Prior to this research, little was known about the disease outside of specific areas of California, Arizona, New Mexico, and Texas [6-8].

In addition to determining where coccidioidomycosis infection is likely to occur, women have also significantly contributed to understanding the clinical outcomes of this disease. While the majority of coccidioidomycosis cases are asymptomatic, the predominant manifestation is primary pulmonary disease in the form of pneumonia [9]. Overall, the disease tends to impact men more than women [10]. However, in recent years, Dr. Rebecca Sunenshine and colleagues analyzed case data in Arizona from 2009 to 2015 and found a slight female predominance [11]. Race is also a factor in increased risk of infection; BIPOC (black, Indigenous, and people of color) women are at greater risk than white women to develop disseminated disease (organ involvement outside of the lungs) and require hospitalization $[12,13]$. Accounting for level of exposure, race alone does not confer an inherent increased risk to inhale the arthroconidia of Coccidioides; occupation, access to and quality of health care, and a variety of research-related bias contribute to this paradigm [12]. Pregnancy is not only a risk factor for coccidioidomycosis, but also for more severe manifestations [14-17]. Acquisition of the disease during pregnancy, especially during the third trimester and postpartum period, increases the likelihood of poor outcomes, including death $[14,18,19]$. Depending on the timing of acquisition during pregnancy, the percent likelihood of disease dissemination ranges from 10 to $96 \%[15,17]$.

Though sometimes overlooked or under cited for their contributions, women have made and continue to make significant achievements in understanding Coccidioides and coccidioidomycosis. We provide an overview of some of the contributions of women to the field of Coccidioides, emphasizing past contributions, current research, and big questions remaining for the field (Figure 1). In addition to specifically naming the women associated with certain contributions, we endorse the claims made throughout our review using many studies led and supported by women.

\section{Environment}

Several questions remain regarding the environmental conditions conducive to the presence of Coccidioides and areas of enhanced risk for contracting coccidioidomycosis, including the dominant reservoir host, favorable soil properties, and ideal climate conditions [20]. Answering these questions has been difficult due to the challenge of acquiring environmental samples of Coccidioides. New molecular-based techniques provide a promising method for detection, which could accelerate research in this area.

\section{The Coccidioides Host Reservoir}

An exact host reservoir for Coccidioides has partially eluded researchers. It has become evident over recent decades that Coccidioides depends on animal species in order to maintain its life cycle [21, 22••]. Comparative genomic studies emphasized a shift from plant tissue-associated genes to animal tissue-associated genes by discovering a significant decrease of genes involved in cell wall degradation (cellulase, tannase, cutinase, and pectin lyase) paired with an expansion of proteases and keratinases suggesting a nutritional association with mammals $[23,24]$. A revival of research from the 1940s [25, $26]$ has steered researchers' attention to rodents and their burrows as the main hypothesis for a dominant host reservoir. Multiple studies have exhibited a higher percentage recovery of Coccidioides from soil collected from rodent burrows than from surrounding topsoil [27-29]. Early on, an experiment performed by Maddy and Crecelius (1967) buried mice that were experimentally infected with Coccidioides in endemic soils that had previously failed to produce cultures of C. immitis for 3 years. Five months after the burial, that soil produced a positive culture and remained positive for 6 subsequent years of investigation, demonstrating sporulation of Coccidioides in the carcasses of dead rodents [30]. Even if rodents are the correct hypothesized dominant reservoir, Rodentia is still the most diverse order within Mammalia, encompassing 2,590 species within 521 genera [31]. Very little research has been conducted to pinpoint a dominant host genus or species. It is possible, if not likely, that $C$. immitis and C. posadasii may be specialized for different host reservoirs, which could vary by geographical region. One species of interest for further investigation in the southwestern US is the desert woodrat (Neotoma lepida), whose presence significantly overlaps with human coccidioidomycosis cases [32].

Although current hypotheses suggest that rodents are the predominant host reservoir, Coccidioides has been detected in a diverse array of wild mammals including bats [33], armadillos [34], sea lions and sea otters [35], llamas and alpacas [36], and numerous non-native zoo animals [21]. The presence of Coccidioides in both terrestrial and marine mammals, as well as volant mammals, suggests that fungal dispersion could take multiple avenues with the migration of their commensal hosts. Coccidioides, present even in low abundance in the lungs [37], may be adapted to proliferate on hair, skin, nails/hooves, and bones of carcasses [38]. This supports an eventual shift in the fungal burden from the host back to the soil; in turn, this maintains the modality of Coccidioides being dispersed by wind or soil disturbance and thus the inhalation of arthroconidia into future hosts. This cycle, in part, could 


\begin{tabular}{|c|c|c|c|}
\hline \multicolumn{2}{|c|}{ Environmental } & $\begin{array}{l}\text { - Coccidioides has a patchy } \\
\text { environmental distribution }\end{array}$ & 8 \\
\hline \multicolumn{2}{|c|}{$\begin{array}{l}\text { Evidence supports an animal } \\
\text { association in the environment }\end{array}$} & $\begin{array}{l}\text { - Climate change may expand or shift } \\
\text { the geographical range of } \\
\text { Coccidioides }\end{array}$ & \\
\hline Big question & \multicolumn{2}{|c|}{$\begin{array}{l}\text { What is the dominant reservoir host and ideal } \\
\text { environmental conditions for Coccidioides growth? }\end{array}$} & \\
\hline \multicolumn{2}{|l|}{ Genetics } & $\begin{array}{l}\text { - C. immitis and C. posadasii differ in } \\
\text { their geographical distribution, which }\end{array}$ & \\
\hline \multicolumn{2}{|c|}{$\begin{array}{l}\text { Understanding evolutionary } \\
\text { population genomics is essential in } \\
\text { pursuit of novel therapeutics }\end{array}$} & $\begin{array}{l}\text { may offer insight into virulence } \\
\text { mechanisms via comparative } \\
\text { genomics }\end{array}$ & \\
\hline Big question & \multicolumn{2}{|c|}{$\begin{array}{l}\text { We know genotypic variation exists; however, what role } \\
\text { does it have on phenotypic variation? }\end{array}$} & \\
\hline \multicolumn{2}{|c|}{ Host Response } & $\begin{array}{l}\text { - Th1 and Th17-type responses are also } \\
\text { important for protection }\end{array}$ & \\
\hline \multicolumn{2}{|c|}{$\begin{array}{l}\text { - The innate host immune response is } \\
\text { crucial for protection against } \\
\text { coccidioidomycosis }\end{array}$} & $\begin{array}{l}\text { A multivalent vaccine with defined } \\
\text { antigens would offer enhanced safety } \\
\text { compared to live attenuated organisms }\end{array}$ & 8 \\
\hline Big question & \multicolumn{2}{|c|}{$\begin{array}{l}\text { Why are some cases of coccidioidomycosis chronic- } \\
\text { is it due to the pathogen, the host, or both? }\end{array}$} & Created with BioRender.com \\
\hline
\end{tabular}

Figure 1. Overview of the paper. Here we highlight the takeaway message from each section along with unanswered questions in the field of Coccidioides research.

supplement the explanation of a geographic range expansion of Coccidioides associated with human migration [39].

\section{Soil, Environmental, and Climatic Conditions}

In addition to the presence of important host reservoirs, certain soil conditions may be favorable habitats for Coccidioides. Drs. Ann Elconin and Margret Egeberg highlighted the significance of studying physical soil properties such as alkalinity and salinity, which may explain some of the heterogeneity in the presence of Coccidioides within each microenvironment $[28,40]$. However, recent correlations between soil properties and the presence of Coccidioides have been inconsistent across studies, making it challenging to draw definitive conclusions. For example, soil properties have been the same where both positive and negative Coccidioides samples were collected [41]. Dr. Antje Lauer and colleagues continue to explore the potential for alkaline soils and the associated vegetation, as well as sandy loam soil textures, to be a favorable soil microenvironment for Coccidioides [42, 43]. In addition to abiotic factors, biotic factors such as microbial competition may also be an important determinant for the presence of Coccidioides [21]. Parsing the differences in preferential abiotic and biotic soil environments between $C$. immitis and C. posadasii would help disentangle any differences in the geographical distribution of these pathogens.

Climate conditions also likely determine the timing and amount of Coccidioides growth within endemic soils.
Coccidioides is thought to proliferate following wet conditions; then if stressed by hot and dry conditions, it will autolyze into arthroconidia that may be easily dispersed by the wind [44]. Although it has not been possible to study this mechanism at the microbial level, human cases of coccidioidomycosis have been correlated with lagged climatic conditions, where cases were higher following dry and warm months [45]. In southern Arizona, temperatures in the preceding season have had a significant positive relationship with coccidioidomycosis incidence [45]. In the San Joaquin Valley of California, autumn levels of human coccidioidomycosis incidence have been higher following cooler and wetter winter and spring months $[46,47]$. Not only do climate conditions affect the seasonal pattern of disease incidence, but they can also modulate the interannual variation in the number of disease cases [45, 46], though this relationship is less clear. Taken in combination, considering the effects of climate conditions with demographic and health risk factors provides a method of calculating a vulnerability index for coccidioidomycosis [48], which can help identify communities most at risk for contracting this disease.

\section{The Geographical Distribution of Coccidioides}

Together, the host reservoirs, soil environment, and climate conditions likely structure the environmental niche and therefore geographical distribution of Coccidioides. Dr. Meritxell Riquelme's lab has been at the forefront of examining where 
Coccidioides lives in the environment. This is imperative to understanding the risk of coccidioidomycosis, especially if the geographical distribution shifts in response to climate change [49]. Soil samples positive for Coccidioides, human coccidioidomycosis case data, and important environmental drivers paired with ecological niche models have made it possible to create high-resolution estimates of the Coccidioides endemic region $[32,50,51 \bullet \cdot$. Using human coccidioidomycosis data as a proxy for Coccidioides presence, Dr. Morgan Gorris and colleagues predict that by the end of the twenty-first century, warming temperatures across the dry, western US may cause the endemic region to expand north $[51 \bullet \bullet]$. This may cause a large increase in the number of people at risk for contracting coccidioidomycosis, the subsequent number of disease cases, and the financial burden of this disease [52]. In contrast, a separate analysis using Coccidioides presence data in a niche model found that by 2070, the geographical distribution of Coccidioides may contract, but the habitat suitability within already suitable locations will increase [32]. Continued disease surveillance and soil sampling will help to further resolve the ecological niche of Coccidioides and discrepancies between estimates, especially as we identify new endemic areas, such as Washington State $[53,54]$. By identifying differences between Coccidioides species, like thermotolerance [55•], we can also determine if there is a niche unique to each species. This will help to delineate the geographical distribution of each species, which may be different than originally thought; for example, C. immitis, originally deemed the "California species," has also been found in New Mexico, Utah, and Washington [53, 56, 57]. Understanding the distribution of Coccidioides will help with assessing human risk for coccidioidomycosis and identifying locations prone to disease outbreaks from activities with large soil disturbance like agriculture, construction, or natural hazards like wildfires, dust storms, and landslides from earthquakes [41, 58-62].

In many ways, future research of Coccidioides is dependent on acquiring environmental samples to supplement clinical and veterinary samples. Although $C$. immitis can be cultured directly from soils, it has proven difficult with one study only obtaining $0.55 \%$ ( 4 out of 720 ) success in a known endemic range of California [63]. For C. posadasii, which has not been directly cultured from soil, Dr. Bridget Barker and collaborators demonstrated that detection is possible using $\mathrm{BALB} / \mathrm{c}$ mice as biosensors in soils near Tucson, Arizona, with a $8.9 \%$ positive detection rate [64]. Intraperitoneal inoculation into mice was also successful in isolating $C$. posadasii from six out of $24(25 \%)$ soil samples from Brazil [65]. A promising, new detection tool developed by Drs. Jolene Bowers and Bridget Barker is the CocciENV real-time PCR assay, which provides a robust way to test a large number of soils for Coccidioides DNA [66]. Although not commonly used in practice, molecular-based technologies exist to differentiate the two species, which may become more essential as we tease apart phenotypic differences [56, 67].

\section{Coccidioides Genetics}

Since the early 1990s, scientists have used classic genetics, and later genomics, to study Coccidioides. Notable contributing researchers include Dr. Bridget Barker, Dr. Chiung-Yu Hung, Dr. Clarisa Nobile, and Dr. Emily Whiston. Together, they and their colleagues have produced a seminal body of research literature identifying key virulence genes and elucidating the role of genetic systems. In parallel, they have utilized and developed a genetic tool kit including genome sequences and editing tools to continue exploring the molecular underpinnings of Coccidioides virulence.

Phenotypic and molecular studies have long suggested that Coccidioides populations differ by region and disease manifestation. There are at least two species of Coccidioides in Western North America, Central America, and South America and the genomic variation within isolates within those sub-populations that can be leveraged to answer longstanding questions about the variable effects of coccidioidomycosis isolates in humans and animals.

\section{Populations and Variance in Genomes}

Genetic and genomic analyses have allowed an understanding of population structure, species level diversity, and evolutionary histories. Better understanding the molecular diversity of Coccidioides and how past evolutionary selective pressures have resulted in current molecular virulence mechanisms will greatly expedite novel therapeutic strategies for treating Coccidioides. Though $C$. posadasii was originally described in 1896, it was not until 2002 when microsatellite and ITS sequence data were available that $C$. immitis and C. posadasii were differentiated [39]. Since then, we have gained appreciation for substantial intraspecific C. posadasii population structure in Texas, Mexico, and South America [22••], and that Arizona has the most diverse isolates of C. posadasii. This is reflected in the asymmetric-genome sequence availability of $C$. posadasii and $C$. immitis isolates, many of which were contributed by women (Table 1 ). Whole-genome sequencing of over 30 new isolates [68] shows that Coccidioides likely originated in the Sonoran Desert.

Whole-genome sequence analyses in Caribbean Coccidioides populations suggest that isolates in Venezuela and surrounding areas have been subjected to a recent bottleneck, and thus their populations are less diverse than their conspecific counterparts with more northern distributions [71]. This molecular diversity distribution pattern across geographical space reinforced earlier findings using a microsatellite marker approach by Fisher et al. [39] suggesting that South 
Table 1. Available genome resources for Coccidioides

\begin{tabular}{|c|c|c|c|}
\hline Species & SRA/NCBI study ${ }^{\mathrm{a}}$ & Sample name ${ }^{\mathrm{b}}$ & Publication $^{c}$ \\
\hline C. immitis & SRP074212 & B0727_Argentina & {$[68]$} \\
\hline C. immitis & SRP148748 & B11080 & [69] \\
\hline C. immitis & SRP148748 & B11518 & {$[70]$} \\
\hline C. immitis & SRP148748 & B11587 & {$[70]$} \\
\hline C. immitis & SRP148748 & B11863 & {$[70]$} \\
\hline C. immitis & SRP148748 & B11873 & {$[70]$} \\
\hline C. immitis & SRP148748 & B12398 & {$[70]$} \\
\hline C. immitis & SRP148748 & B12495 & {$[70]$} \\
\hline C. immitis & SRP148748 & B12496 & {$[70]$} \\
\hline C. immitis & SRP148748 & B13956 & {$[70]$} \\
\hline C. immitis & SRP074212 & Coahuila_1 & {$[68,71]$} \\
\hline C. immitis & SRP074212 & Guerrero_1, RMSCC3479 & {$[68,71]$} \\
\hline C. immitis & PRJNA17355 & H538.4 & {$[72]$} \\
\hline C. immitis & SRP074212 & Michoacan_2, RMSCC3476 & {$[68,71]$} \\
\hline C. immitis & PRJNA17713 & RMSCC2394 & [69] \\
\hline C. immitis & PRJNA17761 & RMSCC3703 & [69] \\
\hline C. immitis & $\begin{array}{l}\text { GCA_000149335.2, AAEC00000000.3, } \\
\text { PRJNA16822 } \\
\text { PRJNA169242 }\end{array}$ & RS & {$[55 \bullet, 69,73]$} \\
\hline C. immitis & SRP042092 & San_Diego_1, RMSCC3706 & {$[53,55 \bullet]$} \\
\hline C. immitis & SRP042092 & San_Joaquin_Valley_11, RMSCC2281 & {$[53,55 \bullet, 70]$} \\
\hline C. immitis & SRP042092 & San_Joaquin_Valley_2, RMSCC22012 & {$[53,55 \bullet]$} \\
\hline C. immitis & SRP042092 & San_Joaquin_Valley_5, RMSCC2268 & {$[53,55 \bullet, 70]$} \\
\hline C. immitis & SRP042092 & San_Joaquin_Valley_6, RMSCC2269 & {$[53,55 \bullet, 70]$} \\
\hline C. immitis & SRP042092 & San_Joaquin_Valley_9, RMSCC2279 & {$[53,55 \bullet, 70]$} \\
\hline C. immitis & SRP074212 & SJV_1, RMSCC2009 & {$[68,70]$} \\
\hline C. immitis & SRP074212 & SJV_10, RMSCC2280 & {$[55 \bullet, 68,70]$} \\
\hline C. immitis & SRP074212 & SJV_3, RMSCC22015 & {$[55 \bullet, 68,70]$} \\
\hline C. immitis & SRP074212 & SJV_4, RMSCC22017 & {$[55 \bullet, 68,70]$} \\
\hline C. immitis & SRP074212 & SJV_7, RMSCC2273 & {$[55 \bullet, 68,70]$} \\
\hline C. immitis & SRP074212 & SJV_8, RMSCC2277 & {$[55 \bullet, 68,70]$} \\
\hline C. immitis & SRP042092 & WA_202, CDC_202, B10992 & {$[53,70,71]$} \\
\hline C. immitis & SRP042092 & WA_205, CDC_205, B10988 & {$[53,70,71]$} \\
\hline C. immitis & SRP042092 & WA_211, CDC_211, B10992 & {$[53,69-71,128]$} \\
\hline C. immitis & SRP042092 & WA_212, BB10996 & {$[53,70,71]$} \\
\hline C. immitis & SRP042092 & Washington_1, B10637 & {$[53,70]$} \\
\hline C. posadasii & SRP135537 & $2566, \mathrm{Cp} \_6$ & [71] \\
\hline C. posadasii & SRP135537 & 34698, Cp_4 & [71] \\
\hline C. posadasii & SRP135537 & $3490, \mathrm{Cp} \_8$ & {$[71]$} \\
\hline C. posadasii & SRP135537 & $3796, \mathrm{Cp} \_5$ & {$[71]$} \\
\hline C. posadasii & SRP135537 & $4542, \mathrm{Cp} \_3$ & {$[71]$} \\
\hline C. posadasii & SRP135537 & 4545-MICE, Cp_2 & {$[71]$} \\
\hline C. posadasii & SRP135537 & $4545, \mathrm{Cp} \_1$ & {$[71]$} \\
\hline C. posadasii & SRP074212 & 730332_Guatemala & {$[68,71]$} \\
\hline C. posadasii & SRP074212 & 730333_Guatelama & {$[68,71]$} \\
\hline C. posadasii & SRP074212 & 730334_Guatemala & {$[68,71]$} \\
\hline C. posadasii & SRP074212 & B0858_Guatemala & {$[68,71]$} \\
\hline C. posadasii & SRP074212 & B10757_Nevada & {$[68,71]$} \\
\hline C. posadasii & SRP074212 & B10813_Texas & {$[68,70,71]$} \\
\hline
\end{tabular}


Table 1. (continued)

\begin{tabular}{|c|c|c|c|}
\hline Species & SRA/NCBI study ${ }^{a}$ & Sample name ${ }^{\mathrm{b}}$ & Publication $^{\mathrm{c}}$ \\
\hline C. posadasii & SRP074212 & B1249_Guatemala & {$[68,71]$} \\
\hline C. posadasii & SRP074212 & B5773_Brazil & {$[68,71]$} \\
\hline C. posadasii & SRP135537 & Beeville & [71] \\
\hline C. posadasii & PRJNA472461 & $\mathrm{C} 735$ & {$[69,23]$} \\
\hline C. posadasii & PRJNA9616 & C735 SOWgp & {$[23,69]$} \\
\hline C. posadasii & SRP074212 & Coahuila_2, RMSCC3506 & {$[55 \bullet, 68,71]$} \\
\hline C. posadasii & SRP074212 & Colorado_Springs_1, VFC047 & {$[68,71]$} \\
\hline C. posadasii & PRJNA17793 & CPA0001 & {$[69]$} \\
\hline C. posadasii & PRJNA17795 & CPA0020 & [69] \\
\hline C. posadasii & PRJNA17797 & CPA0066 & [69] \\
\hline C. posadasii & PRJNA722304 & Flagstaff_1, HS-I-000233 & {$[55 \bullet]$} \\
\hline C. posadasii & PRJNA722304 & Flagstaff_2, HS-I-000234 & {$[55 \bullet]$} \\
\hline C. posadasii & PRJNA722304 & Flagstaff_3, HS-I-000235 & {$[55 \bullet]$} \\
\hline C. posadasii & PRJNA722304 & Flagstaff_4, HS-I-000449 & {$[55 \bullet]$} \\
\hline C. posadasii & PRJNA722304 & Flagstaff_5, HS-I-000588 & {$[55 \bullet]$} \\
\hline C. posadasii & PRJNA722304 & Flagstaff_6, HS-I-000718 & {$[55 \bullet]$} \\
\hline C. posadasii & PRJNA722304 & Flagstaff_7, HS-I-000778 & {$[55 \bullet]$} \\
\hline C. posadasii & SRP074212 & GT002_Texas & {$[68]$} \\
\hline C. posadasii & SRP074212 & GT017_Paraguay & {$[68]$} \\
\hline C. posadasii & SRP135537 & GT120, Cp_9 & {$[71]$} \\
\hline C. posadasii & SRP135537 & GT162, Cp_10 & {$[71]$} \\
\hline C. posadasii & SRP135537 & JTORRES, Cp_7 & {$[71]$} \\
\hline C. posadasii & SRP074212 & Michoacan_1,RMSCC3472 & {$[68,71]$} \\
\hline C. posadasii & SRP074212 & Nuevo_Leon_1, RMSCC2343 & {$[55 \bullet, 68,71]$} \\
\hline C. posadasii & SRP074212 & Nuevo_Leon_2, RMSCC2346 & {$[55 \bullet, 68,71]$} \\
\hline C. posadasii & SRP074212 & Phoenix_1, ID02-184 & {$[68,71]$} \\
\hline C. posadasii & SRP074212 & Phoenix_2, ID03-517 & {$[68,71]$} \\
\hline C. posadasii & SRP074212 & Phoenix_3, ID03-584 & {$[68,71]$} \\
\hline C. posadasii & SRP074212 & Phoenix_4, ID03-587 & {$[68,71]$} \\
\hline C. posadasii & SRP074212 & Phoenix_5, 0204-3538 & {$[68,71]$} \\
\hline C. posadasii & SRP074212 & Phoenix_6, 0204-5786 & {$[68,71]$} \\
\hline C. posadasii & SRP074212 & Phoenix_7, 0204-7892 & {$[68,71]$} \\
\hline C. posadasii & SRP074212 & Phoenix_8, 0204-9888 & {$[68,71]$} \\
\hline C. posadasii & SRP074212 & Phoenix_9, 0205-5127 & {$[68,71]$} \\
\hline C. posadasii & PRJNA17791 & RMSCC1037 & [69] \\
\hline C. posadasii & PRJNA17785 & RMSCC1038 & [69] \\
\hline C. posadasii & PRJNA17763 & RMSCC2133 & {$[69]$} \\
\hline C. posadasii & PRJNA17783 & RMSCC3488 & {$[69]$} \\
\hline C. posadasii & PRJNA17781 & RMSCC 3700 & [69] \\
\hline C. posadasii & SRP074212 & San_Antonio_1 & {$[68,71]$} \\
\hline C. posadasii & GCA_000170175.2 & Silveira & {$[55 \cdot, 72,129]$} \\
\hline C. posadasii & SRP074212 & Sonora_1, RMSCC3480 & {$[55 \bullet, 68]$} \\
\hline C. posadasii & SRP074212 & Sonora_2, RMSCC3487 & {$[55 \bullet, 68]$} \\
\hline C. posadasii & SRP074212 & Tucson_1, RMSCC3214 & {$[68,71]$} \\
\hline C. posadasii & SRP074212 & Tucson_10, RMSCC3252 & {$[68,71]$} \\
\hline C. posadasii & SRP074212 & Tucson_11, RMSCC3253 & {$[68,71]$} \\
\hline C. posadasii & SRP074212 & Tucson_12, RMSCC3262 & {$[68,71]$} \\
\hline C. posadasii & SRP074212 & Tucson_13, RMSCC3263 & {$[68,71]$} \\
\hline C. posadasii & SRP074212 & Tucson_14, RMSCC3268 & {$[68,71]$} \\
\hline
\end{tabular}


Table 1. (continued)

\begin{tabular}{|c|c|c|c|}
\hline Species & SRA/NCBI study ${ }^{a}$ & Sample name ${ }^{\mathrm{b}}$ & Publication $^{\mathrm{c}}$ \\
\hline C. posadasii & SRP074212 & Tucson_15, RMSCC3273 & {$[68,71]$} \\
\hline C. posadasii & SRP074212 & Tucson_16, RMSCC3275 & {$[68,71]$} \\
\hline C. posadasii & SRP074212 & Tucson_17, RMSCC3289 & {$[68,71]$} \\
\hline C. posadasii & SRP074212 & Tucson_18, RMSCC3299 & {$[68,71]$} \\
\hline C. posadasii & SRP074212 & Tucson_19, RMSCC3300 & {$[68,71]$} \\
\hline C. posadasii & SRP074212 & Tucson_2, RMSCC3223 & {$[68,71]$} \\
\hline C. posadasii & SRP074212 & Tucson_20, RMSCC3305 & {$[68,71]$} \\
\hline C. posadasii & SRP074212 & Tucson_21, RMSCC3317 & {$[68,71]$} \\
\hline C. posadasii & SRP074212 & Tucson_22, RMSCC3319 & {$[68,71]$} \\
\hline C. posadasii & SRP074212 & Tucson_23, RMSCC3474 & {$[68,71]$} \\
\hline C. posadasii & SRP074212 & Tucson_24 & {$[68,71]$} \\
\hline C. posadasii & SRP074212 & Tucson_3, RMSCC3230 & {$[68,71]$} \\
\hline C. posadasii & SRP074212 & Tucson_4, RMSCC3231 & {$[68,71]$} \\
\hline C. posadasii & SRP074212 & Tucson_5, RMSCC3234 & {$[68,71]$} \\
\hline C. posadasii & SRP074212 & Tucson_6, RMSCC3238 & {$[68,71]$} \\
\hline C. posadasii & SRP074212 & Tucson_7, RMSCC3240 & {$[68,71]$} \\
\hline C. posadasii & SRP074212 & Tucson_8, RMSCC3247 & {$[68,71]$} \\
\hline C. posadasii & SRP074212 & Tucson_9, RMSCC3248 & {$[68,71]$} \\
\hline
\end{tabular}

American populations are younger and less diverse. C. posadasii spread to South America 9,000-14,000 years ago, concomitant with human migration patterns and was potentially disseminated by our infected ancestors. While there are fewer genome sequences available and less molecular diversity within C. immitis (Table 1), population analyses suggest that there are at least two sub-populations, one in Washington State and the other in Central and Southern California [53, 71]. In their overlapping geographic regions in Southern California and Northern Mexico, we observe signals of introgression between C. immitis and C. posadasii including within the well-studied isolate $C$. immitis RS. Several considerations should be taken by future researchers when analyzing Coccidioides genomic data. First, they should take care to note potential hybridized isolates and the implications for variant identification when selecting reference genomes for alignment-based inferences. Second, while many Coccidioides sequences are available on the NCBI Short Read Archive (SRA), a few assemblies including C. immitis RS, C. posadasii C735, and Silveira are only on the NCBI database (Table 1). Last, there are several Coccidioides isolates that have been published under multiple strain names (Table 1). The genome sequencing era has provided ample opportunity to utilize long-standing tools from evolutionary biology to gain insight into Coccidioides virulence genetics, providing targets for novel therapeutic design. Cross disciplinary approaches utilizing whole genome sequencing data, evolutionary genomics, and species level diversity are likely to continue unraveling how fungal genomic diversity contributes to our complex interactions with Coccidioides.

\section{Phenotypic Variation}

Coccidioides genomic content and structure divergence mirrors speciation between $C$. immitis and $C$. posadasii and has resulted in phenotypic differences noted between the species. Environmental conditions in the native geographic range of $C$. posadasii compared to $C$. immitis likely vary in many ways, including soil biochemistry, salinity, temperature, and mammalian host population. Early work on interspecific phenotypic variation showed that single isolates exhibit differential growth in response to salinity, temperature, and humidity [74, 75]. Later, analyses of relatively small populations ( $<10$ individuals) documented differences in fungal growth rates on high salt media, further suggesting that $C$. immitis is more salt tolerant than C. posadasii [76]. Indeed, many scientists agree that salinity, temperature, and other environmental variables strongly shape Coccidioides physiology and distribution [40, 55•, $77,78]$. The first study to interrogate phenotypic variation in a robust population of 39 C. posadasii and 46 C. immitis isolates [55•] noted that while C. posadasii and C. immitis had similar growth rates at $28^{\circ} \mathrm{C}, \mathrm{C}$. posadasii grew significantly faster at $37^{\circ} \mathrm{C}$. Earlier work from the same group suggested that $C$. immitis produces spherules synchronously during in vitro culture where $C$. posadasii does not [79]. Though the two species exist in considerably different environments, and phenotypic variation in key virulence traits are currently being investigated, so far there has been no difference clinically between the species [80], and 
accordingly, currently available diagnostic tools do not differentiate at the species level.

Future efforts focused on publishing robust phenotypic data and the connections to genotypic data will help the Coccidioides research community understand connections between life cycle phases spent in the environment and their relationship to virulence factors observed in clinics. Further, efforts focused on molecular diversity underpinning sporulation and dispersal dynamics, range expansion, and host affiliation will enable robust predictive modeling and inform pandemic preparedness.

\section{Virulence Genetics}

The Coccidioides genome contains $\sim 7,000-9,000$ protein coding genes, and nearly half lack functional gene annotation predictions [71]. While it is clear that expansions and contractions of gene families have enabled Coccidioides and other fungi in Onygenales to target animal cell wall degradation rather than plant cell walls, functionality of the Coccidioides genome as a whole remains relatively poorly understood. It is an exciting time to be a Coccidioides genomics researcher, as the $\sim 50 \%$ of genes with annotations based on homology to known orthologs in other fungi may lack relevance due to the unique cellular structures Coccidioides produced during infections, including the spherule. As in all genome annotation endeavors, targeted gene deletion is needed to confirm functions based on computational gene annotation and functional and genomic screens. In total, less than 10 genes have been functionally characterized in Coccidioides, many of which appear to be related to virulence [81-87]. For example, deletion of urease gene (URE) partially reduced ammonia production and increased mice survival by $60 \%$ [88]. Further, double deletion of urease gene (URE) Ureidoglycolate hydrolase (Ugh) resulted in even lower extracellular ammonia levels and increased mice survival to $90 \%$. These findings are supported by direct measurements, transcriptome, and volatome analyses which show that ammonia production contributes to virulence during spherule development and rupture. In another multiple gene deletion strategy, Dr. Chiung-Yu Hung et al. created a completely avirulent strain of Coccidioides as a vaccine candidate through partial deletion of chitinase genes among others (cts2/ard1/cts 3 or $\Delta \mathrm{T})$ [83]. Loss of virulence appears to be associated with genes responsible for intracellular chitin remodeling leading to multiple changes at a transcriptional level preventing spherule rupture.

To date, all gene deletions have been completed within the C. posadasii, wildtype C735 background and one in C. posadasii strain, Silveira; therefore, intra- or interspecies virulence gene sequence variation has yet to be assessed (Table 1) [81]. However, the broad spectrum of disease symptoms in humans coupled with strong regional population genetic variation among Coccidioides isolates suggests that virulence mechanisms and severity may co-vary by species or region. Investigations by Dr. Emily Whiston showed that transcriptional patterns are generally shared between species but approximately 500 genes are differentially expressed during parasitic phase spherule growth, suggesting unique gene usage between species [73]. Phenotypic differences have been documented between species, including differential thermotolerance behavior [89], saline tolerance [76], and spherule growth patterns [79]. However, the underlying gene functions associated with these phenotypes remain largely unknown. Lewis et al. identified that mice infected with equivalent fungal inoculum had increased fungal burden and $i l-1 \beta$ response to $C$. posadasii Silveira isolate but not to C. immitis 2006 or RS [90], potentially indicating hypervirulence in some isolates. Linking virulence to gene sequence and function is a top research priority. Progress in this realm is underscored by variation in the gene sequence of SOWgp (spherule outer wall protein), an extracellular glycoprotein which binds to host cells. The SOWgp deletion mutant demonstrated decreased binding in vitro and virulence in vivo. While the current SOWgp mutant was created in the $C$. posadasii background, molecular techniques revealed that other strains of C. posadasii showed variation in SOWgp protein size and quantity of repeats, which could potentially alter function [86], and SOWgp sequence variation within C. immitis is unknown. As previously mentioned, a successful gene editing strategy for $C$. immitis has not been developed, thus hindering gene function comparisons between species.

In an era of advanced genetic and genomic technologies, it may come as a surprise that such a small handful of genes have been functionally characterized and primarily in one C. posadasii isolate. Research progress in this area has been severely limited by development of genome editing tools for Coccidioides [91]. Current strategies use either introduction of linear DNA to susceptible protoplasts or Agrobacterium-mediated transformation, the latter of which appears more efficient. Challenges for efficient transformation include polynucleate arthroconidia, persistence of heterokaryons following transformation selection, and logistics of biosafety level three (BSL3) laboratory experiments [85, 92]. Creation of autotrophic mutants [93] or CRISPR Cas9 [94] technologies have proven successful approaches in other fungal pathogens but have yet to be applied to Coccidioides.

\section{Host Immune Response and Development of a Vaccine}

The progress of vaccine and immunology research in the Coccidioides field is largely thanks to the women researchers in the field. There are some excellent women-led review articles highlighting the recent advances in the immune response, host-pathogen interactions, and development of a Coccidioides vaccine [95•, 96-98, 99•]. In this section, we 
will discuss briefly what is known about the host immune response to Coccidioides and the development of a vaccine to combat coccidioidomycosis.

\section{Host Immune Response}

The innate immune response is the first line of defense against many fungal pathogens, especially macrophages and neutrophils. Dr. Chiung-Yu Hung has shown that neutrophils are increased significantly during a Coccidioides infection [100]. Her work has shown that the role of neutrophils is not a one size fits all scenario. On one hand, mice depleted of neutrophils during a primary infection are just as susceptible as wildtype mice [101]. Mice vaccinated with a live, attenuated $(\Delta \mathrm{T}$ vaccine) strain require neutrophils to be protected against challenge with Coccidioides. Vaccination studies have also shown an increased presence of macrophages in vaccinated mice compared to unvaccinated mice after challenge with Coccidioides [100]. Furthermore, studies show that mouse peritoneal macrophages produce tumor necrosis factor alpha, TNF- $\alpha$, when stimulated with Coccidioides spherules [102]. Pattern recognition receptors (PRRs) such as toll-like receptors (TLRs) and C-type Lectin receptors interact with cell components or pathogen-associated molecular patterns (PAMPs) to detect Coccidioides [103]. Using peritoneal macrophages from wild-type and knockout mice (TLR2 ${ }^{-/}$and MyD $\left.88^{-/}\right)$, studies have shown that host response to Coccidioides spherules relies on TLR2, myeloid differentiation factor 88 (MyD88), and Dectin-1 [104]. Furthermore, studies suggest that alternative splicing of Dectin-1 in C57BL/6 mice causes increased susceptibility to coccidioidomycosis [105]. Studies performed by Dr. Althea Campuzano and colleagues has shown that macrophages isolated from Dectin- $1^{-/-}$, Dectin $2^{-/}$, and CARD9 ${ }^{-/-}$mice produced less inflammatory cytokines in response to the GCP-rCpal vaccine compared to wild-type mice [106•]. Additionally, these studies demonstrate less efficacy of the GCP-rCpal vaccine in Dectin- ${ }^{-/-}$, Dectin $2^{-/-}$, and CARD ${ }^{-/-}$mice compared to vaccinated wild-type mice. Although much remains to be done, these studies demonstrate the crucial role of the innate immune response to protect against coccidioidomycosis.

$\mathrm{T}$ cells have been shown to be critical for protection against coccidioidomycosis. $\mathrm{CD} 4^{+} \mathrm{T}$ cell deficiency leads to increased susceptibility to a Coccidioides infection [107]. Furthermore, $\mathrm{CD} 4{ }^{+} \mathrm{T}$ cells differentiate into distinct lineages based on cytokines produced in response to a pathogen. A T cell helper 1 (Th1) response is associated with cytokines such as IL-12 and IFN- $\gamma$ and has been shown to be important for protection against coccidioidomycosis [83, 108], while a Th2-type response, activated by cytokines such as IL-4 and IL-5, has been shown to downregulate the immune response during a Coccidioides infection [83]. Th17 responses, activated by IL-17 and IL-22, have been shown to be critical for protection against coccidioidomycosis [109]. Studies to understand the host immune response to Coccidioides mainly use C. posadasii as a model and assume $C$. immitis to have a similar response; however, more studies are needed to discern this.

\section{Vaccine Development}

There is no clinically available vaccine against any human fungal pathogen. Interestingly, a Candida albicans vaccine, NDV-3A, demonstrates promise in clinical trials against recurrent vulvovaginal candidiasis [110], the potential to prevent colonization on medical devices [111], and even prevent against $C$. auris infection [112]. Many live attenuated strains have demonstrated protection against coccidioidomycosis; however, live vaccines are not preferred due to their potential safety concerns [113]. Some of the live attenuated candidates include $\Delta \mathrm{T}$ (also known as $\Delta$ cts $2 / \operatorname{ardl} / \mathrm{cts} 3$ ) $[83,100,114]$ and $\triangle$ CPS1 $[81,115]$. Dr. Lisa Shubitz and colleagues are

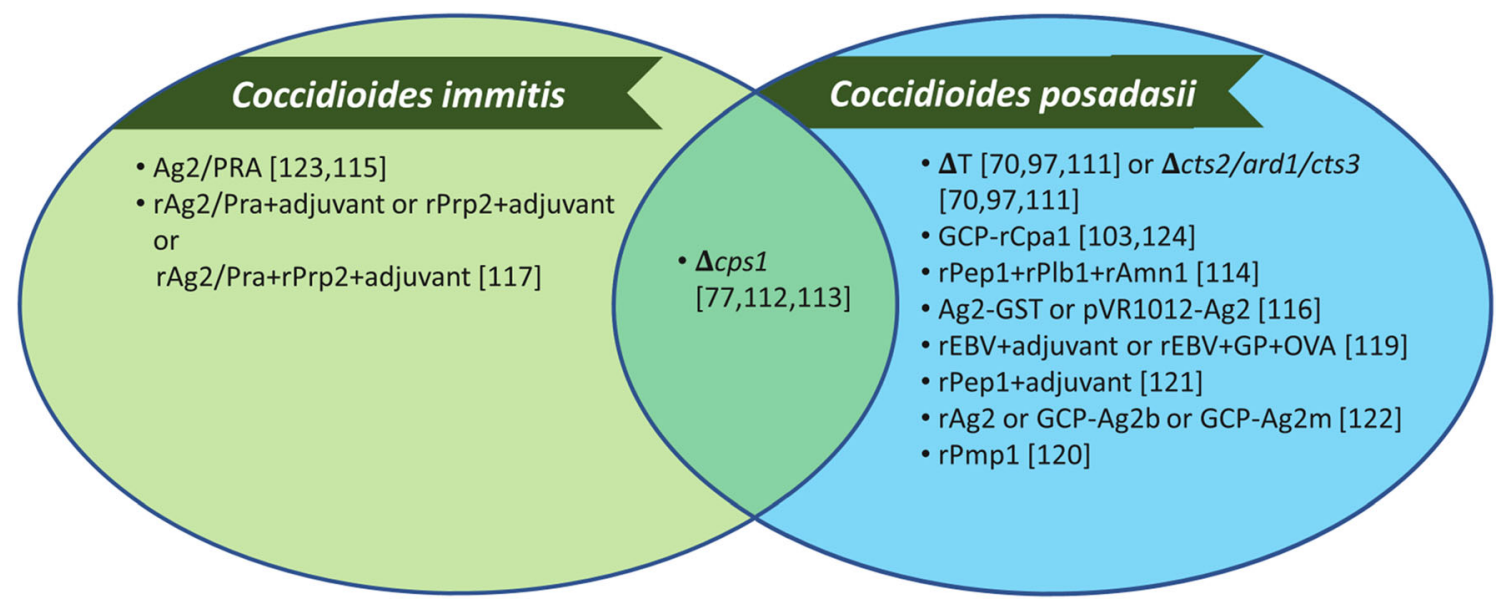

Figure 2. Species tested with coccidioidomycosis vaccine candidates. Vaccination studies against coccidioidomycosis mainly test against $C$. posadasii infections. 
developing $\triangle$ CPS1 as a vaccine candidate to prevent infection due to $C$. posadasii in dogs [116]. Many studies have identified protective antigens (Pep1, Plb, Amn1, Ag2/Pra, Cs-Ag, Pmp1, Prp2, Ure, and Gel1) that could be used in a recombinant protein vaccine [117-125]. Although these studies demonstrated varying levels of protection, the use of multivalent vaccines shows more efficacy than a single peptide vaccine against coccidioidomycosis $[117,126]$. Dr. Chiung-Yu Hung and colleagues have developed a multivalent vaccine encapsulated in glucan-chitin particles, GCP-rCpa1, that has demonstrated increased survival, significantly reduced fungal burden, and showed a protective Th1 and Th17 response against C. posadasii in a murine model of coccidioidomycosis [127]. Furthermore, recent studies have shown that protection mediated by the GCP-rCpal vaccine is due to enhancement of Th17 responses and activation of CARD9-associated Dectin1 and Dectin-2 signal pathways [106•]. A majority of the vaccination studies against coccidioidomycosis demonstrate protection mainly against $C$. posadasii infections $[81,83$, $100,106 \bullet, 114,116,117,119,122-127]$. There are a couple studies that demonstrate protection against $C$. immitis $[118$, 120] and only one study to demonstrate protection against both species [115] (Figure 2).

\section{Antifungal Drugs}

Antifungal medications from the triazole and polyene classes are the mainstay of treatment for coccidioidomycosis. Dr. Marley Van Dyke et al. recently summarized the agents with coverage of Coccidioides along with potential novel agents [95•]. While robust, prospective studies investigating the most appropriate treatment are lacking, fluconazole, an oral and intravenous triazole, is the most prescribed treatment and recommended as the firstline agent for primary pulmonary infection [70]. It is important to note that treatment is not always warranted, especially in the setting of uncomplicated, mild disease [70]. In cases of severe infection with dissemination and/or meningitis, amphotericin B, an intravenous polyene agent, is used as induction therapy. Amphotericin B requires intense laboratory monitoring and is typically prescribed with the aid of an infectious diseases specialist, as it can cause renal and hepatotoxicity along with infusion reactions [95•]. Investigation of novel antifungal agents for treatment of coccidioidomycosis will be crucial to expand our arsenal for disease treatment.

\section{Conclusion}

Women have pioneered Coccidioides and coccidioidomycosis research in the past, shedding light on previous large questions in the field. While numerous big questions remain regarding the environmental, genetic, and clinical aspects of this disease, it is important that the Coccidioides community continues to acknowledge and support the work of women, as well as push for further diversity and inclusion regarding this disease. Doing so will strengthen the scientific research being done on Coccidioides and likely mitigate some of the negative health outcomes from coccidioidomycosis.

Acknowledgements The authors gratefully acknowledge the contributions from women in the field of Coccidioides. Dr. Gorris thanks the Laboratory Directed Research and Development (LDRD) program and the Center for Nonlinear Studies at Los Alamos National Laboratory. Dr. Van Dyke would like to thank her sister, Sylena Measles, for helping format the figures.

Author Contribution All authors made substantial contributions to the conception and design of the review. All authors contributed to writing the manuscript and approved the final version.

Funding M. E. Gorris was funded by a Director's Postdoctoral Fellowship from the Los Alamos National Laboratory Directed Research and Development program.

Data Availability Not applicable.

Code Availability Not applicable.

\section{Declarations}

Ethics Approval Not applicable.

Consent to Participate Not applicable.

Consent for Publication This work is approved for distribution under LA-UR-21-23354. The findings and conclusions in this report are those of the authors and do not necessarily represent the official position of Los Alamos National Laboratory. Los Alamos National Laboratory, an affirmative action/equal opportunity employer, is managed by Triad National Security, LLC, for the National Nuclear Security Administration of the US Department of Energy under contract 89233218CNA000001.

Conflict of Interest Dr. Gorris, Dr. Van Dyke, Dr. Carey, Paris Hamm, Dr. Heather Mead, and Dr. Uehling have nothing to disclose.

Additional Declarations for Articles in Life Science Journals that Report the Results of Studies Involving Humans and/or Animals Not applicable.

Open Access This article is licensed under a Creative Commons Attribution 4.0 International License, which permits use, sharing, adaptation, distribution and reproduction in any medium or format, as long as you give appropriate credit to the original author(s) and the source, provide a link to the Creative Commons licence, and indicate if changes were made. The images or other third party material in this article are included in the article's Creative Commons licence, unless indicated otherwise in a credit line to the material. If material is not included in the article's Creative Commons licence and your intended use is not permitted by statutory regulation or exceeds the permitted use, you will need to obtain permission directly from the copyright holder. To view a copy of this licence, visit http://creativecommons.org/licenses/by/4.0/. 


\section{References}

Papers of particular interest, published recently, have been highlighted as:

- Of importance

•- Of major importance

1. Ainsworth G. Introduction to the history of medical and veterinary mycology: Cambridge Univ. Press; 2002.

2. Gifford MDE. Coccidioides infection (coccidioidomycosis). Arch Intern Med (Clic). 1938;62(5):853-71.

3. Gifford MA, Buss WC, Douds RJ. Data on Coccidioides fungus infection, Kern County, 1901-1936. Annual Report Kern County Health Department for the Fiscal Year July 1, 1936, to June 30, 1937. 1937;39-54.

4. Dr. Myrnie Gifford | CSUB Library Archives eDocent. https:// csubedocent.wordpress.com/2015/02/20/dr-myrnie-gifford/. Accessed 14 Mar 2021

5. Edwards PQ, Palmer CE. Prevalence of sensitivity to coccidioidin, with special reference to specific and nonspecific reactions to coccidioidin and to histoplasmin. Dis Chest. 1957;31:35-60. https://doi.org/10.1378/chest.31.1.35.

6. Williams J, Ellingson H. Studies on coccidioidomycosis at Air Force bases in the southwestern United States. United States Air Force Air University School of Aviation Medicine. 1954.

7. Smith C. Coccidioidomycosis. Med Clin North Am. 1943;27: 790-807.

8. Lee R. Coccidioidomycosis in the Western Flying Training Command. Calif West Med. 1944;61:113.

9. Blair JE, Chang Y-HH, Cheng M-R, Vaszar LT, Vikram HR, Orenstein R, et al. Characteristics of patients with mild to moderate primary pulmonary coccidioidomycosis. Emerg Infect Dis. 2014;20:983-90. https://doi.org/10.3201/eid2006.131842.

10. Brown J, Benedict K, Park BJ, Thompson GR. Coccidioidomycosis: epidemiology. Clin Epidemiol. 2013;5: 185-97. https://doi.org/10.2147/CLEP.S34434.

11. McCotter OZ, Benedict K, Engelthaler DM, et al. Update on the epidemiology of coccidioidomycosis in the United States. Med Mycol. 2019;57:S30-40. https://doi.org/10.1093/mmy/myy095.

12. Ruddy BE, Mayer AP, Ko MG, Labonte HR, Borovansky JA, Boroff ES, et al. Coccidioidomycosis in African Americans. Mayo Clin Proc. 2011;86:63-9. https://doi.org/10.4065/mcp. 2010.0423.

13. McCotter O, Kennedy J, McCollum J, Bartholomew M, Iralu J, Jackson BR, et al. Coccidioidomycosis among American Indians and Alaska natives, 2001-2014. Open Forum Infect Dis. 2019;6: ofz052. https://doi.org/10.1093/ofid/ofz052.

14. Bercovitch RS, Catanzaro A, Schwartz BS, Pappagianis D, Watts $\mathrm{DH}$, Ampel NM. Coccidioidomycosis during pregnancy: a review and recommendations for management. Clin Infect Dis. 2011;53: 363-8. https://doi.org/10.1093/cid/cir410.

15. Crum NF, Ballon-Landa G. Coccidioidomycosis in pregnancy: case report and review of the literature. Am J Med. 2006;119: 993.e11-7. https://doi.org/10.1016/j.amjmed.2006.04.022.

16. Wack EE, Ampel NM, Galgiani JN, Bronnimann DA. Coccidioidomycosis during pregnancy. An analysis of ten cases among 47,120 pregnancies. Chest. 1988;94:376-9. https://doi. org/10.1378/chest.94.2.376.

17. Caldwell JW, Arsura EL, Kilgore WB, Garcia AL, Reddy V, Johnson RH. Coccidioidomycosis in pregnancy during an epidemic in California. Obstet Gynecol. 2000;95:236-9. https://doi. org/10.1016/s0029-7844(99)00484-6.

18. Vaughan JE, Ramirez H. Coccidioidomycosis as a complication of pregnancy. Calif Med. 1951;74:121-5.
19. Smale LE, Waechter KG. Dissemination of coccidioidomycosis in pregnancy. Am J Obstet Gynecol. 1970;107:356-61. https://doi. org/10.1016/0002-9378(70)90557-0.

20. Nguyen C, Barker BM, Hoover S, Nix DE, Ampel NM, Frelinger JA, et al. Recent advances in our understanding of the environmental, epidemiological, immunological, and clinical dimensions of coccidioidomycosis. Clin Microbiol Rev. 2013;26:505-25. https://doi.org/10.1128/CMR.00005-13.

21. del Rocío R-MM, Pérez-Huitrón MA, Ocaña-Monroy JL, FríasDe-León MG, Martínez-Herrera E, Arenas R, et al. The habitat of Coccidioides spp. and the role of animals as reservoirs and disseminators in nature. BMC Infect Dis. 2016;16:550. https://doi. org/10.1186/s12879-016-1902-7.

22.• Taylor JW, Barker BM. The endozoan, small-mammal reservoir hypothesis and the life cycle of Coccidioides species. Med Mycol. 2019;57:S16-20. https://doi.org/10.1093/mmy/myy039 Synthesizes findings from multiple studies to hypothesize small-mammals are the reservoir for Coccidioides.

23. Sharpton TJ, Stajich JE, Rounsley SD, Gardner MJ, Wortman JR, Jordar VS, et al. Comparative genomic analyses of the human fungal pathogens Coccidioides and their relatives. Genome Res. 2009;19:1722-31. https://doi.org/10.1101/gr.087551.108.

24. Li J, Zhang K-Q. Independent expansion of zincin metalloproteinases in Onygenales fungi may be associated with their pathogenicity. PLoS One. 2014;9:e90225. https://doi.org/10.1371/journal. pone.0090225.

25. Emmons CW. Isolation of Coccidioides from soil and rodents. Public Health Rep. 1942;57:109. https://doi.org/10.2307/ 4583988.

26. Emmons CW, Ashburn LL. The isolation of Haplosporangium parvum n. sp. and Coccidioides immitis from wild rodents. Their relationship to coccidioidomycosis. Public Health Rep. 1942;57: 1715. https://doi.org/10.2307/4584276.

27. Kollath DR, Miller KJ, Barker BM. The mysterious desert dwellers: Coccidioides immitis and Coccidioides posadasii, causative fungal agents of coccidioidomycosis. Virulence. 2019;10: 222-33. https://doi.org/10.1080/21505594.2019.1589363.

28. Lacy GH, Swatek FE. Soil ecology of Coccidioides immitis at Amerindian middens in California. Appl microbiol. 1974;27(2): 379-388. https://doi.org/10.1128/am.27.2.379-388.1974.

29. Cordeiro RA, Brilhante RSN, Rocha MFG, Fechine MAB, Camara LMC, Camargo ZP, et al. Phenotypic characterization and ecological features of Coccidioides spp. from Northeast Brazil. Med Mycol. 2006;44:631-9. https://doi.org/10.1080/ 13693780600876546

30. Maddy K, Crecelius H. Establishment of Coccidioides immitis in negative soil following burial of infected animals and animal tissues. In: Pap. from 2nd Symp. Coccidioidomycosis. Tucson: University of Arizona Press; 1967. p. 309-12.

31. ASM Mammal Diversity Database. http://www.mammaldiversity. org/. Accessed 19 Mar 2021

32. Ocampo-Chavira P, Eaton-Gonzalez R, Riquelme M. Of mice and fungi: Coccidioides spp. Distribution Models. J Fungi. 2020;6: 320. https://doi.org/10.3390/jof6040320.

33. de Aguiar CR, de Castro e Silva KR, Brilhante RSN, et al. Coccidioides posadasii infection in bats, Brazil. Emerg Infect Dis. 2012;18:668-70. https://doi.org/10.3201/eid1804.111641.

34. Eulalio KD, De Macedo RL, Salmito Cavalcanti MDA, Soares Martins LM, Lazéra MDS, Wanke B. Coccidioides immitis isolated from armadillos (Dasypus novemcinctus) in the state of Piauí, northeast Brazil. Mycopathologia. 2001;149:57-61. https://doi. org/10.1023/A:1007273019647.

35. Huckabone SE, Gulland FMD, Johnson SM, Colegrove KM, Dodd EM, Pappagianis D, et al. Coccidioidomycosis and other systemic mycoses of marine mammals stranding along the central 
California, USA coast: 1998-2012. J Wildl Dis. 2015;51:295308. https://doi.org/10.7589/2014-06-143.

36. Grayzel SE, Thompson GR, Martínez-López B, Dechant JE, McHardy I, Sykes JE. Coccidioidomycosis in llamas and alpacas diagnosed at the University of California, Davis (1990-2016). Med Mycol. 2020. https://doi.org/10.1093/mmy/myaa082.

37. Hamm PS, Taylor JW, Cook JA, Natvig DO. Decades-old studies of fungi associated with mammalian lungs and modern DNA sequencing approaches help define the nature of the lung mycobiome. PLoS Pathog. 2020;16:e1008684. https://doi.org/ 10.1371/journal.ppat.1008684

38. Sharmin S, Kishi F, Sano A, Kamei K, Nishimura K, Miyaji M. Direct invasion of bones by highly pathogenic fungi in an in vitro model and its ecological significance. Jpn J Med Mycol. 2003;44: 17-23. https://doi.org/10.3314/jjmm.44.17.

39. Fisher MC, Koenig GL, White TJ, San-Blas G, Negroni R, Gutiérrez Alvarez I, et al. Biogeographic range expansion into South America by Coccidioides immitis mirrors new world patterns of human migration. Proc Natl Acad Sci U S A. 2001;98: 4558-62. https://doi.org/10.1073/pnas.071406098.

40. Elconin AF, Egeberg RO, Egeberg MC. Significance of soil salinity on the ecology of Coccidioides immitis. Journal of bacteriology. 1964;87(3):500-503. https://doi.org/10.1128/jb.87.3.500503.1964.

41. Lauer A, Lopez J, Abarca S, Bains J. Earthquake-ridden area in USA contains Coccidioides, the Valley Fever Pathogen. Ecohealth. 2020;17:248-54. https://doi.org/10.1007/s10393-02001485-w.

42. Lauer A, Etyemezian V, Nikolich G, Kloock C, Arzate AF, Sadiq Batcha F, et al. Valley Fever: environmental risk factors and exposure pathways deduced from field measurements in California. Int J Environ Res Public Health. 2020;17:5285. https://doi.org/10. 3390/ijerph17155285.

43. Lauer A, Baal JDH, Baal JCH, Verma M, Chen JM. Detection of Coccidioides immitis in Kern County, California, by multiplex PCR. Mycologia. 2012;104:62-9. https://doi.org/10.3852/11-127.

44. Smith CE, Beard RR, Rosenberger HG, Whiting EG. Effect of season and dust control on coccidioidomycosis. J Am Med Assoc. 1946;132:833-8. https://doi.org/10.1001/jama.1946. 02870490011003 .

45. Kolivras KN, Comrie AC. Modeling valley fever (coccidioidomycosis) incidence on the basis of climate conditions. Int J Biometeorol. 2003;47:87-101. https://doi.org/10. 1007/s00484-002-0155-x.

46. Gorris ME, Cat LA, Zender CS, Treseder KK, Randerson JT. Coccidioidomycosis dynamics in relation to climate in the Southwestern United States. GeoHealth. 2018;2:6-24. https:// doi.org/10.1002/2017GH000095.

47. Weaver EA, Kolivras KN. Investigating the relationship between climate and valley fever (coccidioidomycosis). Ecohealth. 2018;15:840-52. https://doi.org/10.1007/s10393-018-1375-9.

48. Shriber J, Conlon K, Benedict K, McCotter O, Bell J. Assessment of vulnerability to coccidioidomycosis in Arizona and California. Int J Environ Res Public Health. 2017;14:680. https://doi.org/10. 3390/ijerph14070680.

49. Baptista-rosas RC, Catalán-dibene J, Romero-olivares AL, Hinojosa A, Cavazos T, Riquelme M. Molecular detection of Coccidioides spp. from environmental samples in Baja California: linking Valley Fever to soil and climate conditions. Fungal Ecol. 2012;5:177-90. https://doi.org/10.1016/j.funeco. 2011.08.004.

50. Baptista-Rosas RC, Hinojosa A, Riquelme M. Ecological niche modeling of Coccidioides spp. in western North American deserts. In: Ann. N. Y. Acad. Sci, vol. 1111: Blackwell Publishing Inc; 2007. p. 35-46. https://doi.org/10.1196/annals.1406.003.
51.• Gorris ME, Treseder KK, Zender CS, Randerson JT. Expansion of Coccidioidomycosis endemic regions in the United States in response to climate change. GeoHealth. 2019;3:308-27. https:// doi.org/10.1029/2019GH000209 Analyzes the relationships between climate and the endemic region of Coccidioides, including how the endemic range may shift in response to climate change.

52. Gorris ME, Neumann JE, Kinney PL, Sheahan M, Sarofim AC. Economic valuation of coccidioidomycosis (valley fever) projections in the United States in response to climate change. Weather Clim Soc. 2021;13:107-23. https://doi.org/10.1175/WCAS-D20-0036.1.

53. Litvintseva AP, Marsden-Haug N, Hurst S, Hill H, Gade L, Driebe $\mathrm{EM}$, et al. Valley Fever: finding new places for an old disease: Coccidioides immitis found in Washington State soil associated with recent human infection. Clin Infect Dis. 2015;60:e1-3. https://doi.org/10.1093/cid/ciu681.

54. Marsden-Haug N, Goldoft M, Ralston C, Limaye AP, Chua J, Hill $\mathrm{H}$, et al. Coccidioidomycosis acquired in Washington State. Clin Infect Dis. 2013;56:847-50. https://doi.org/10.1093/cid/cis1028.

55. Mead HL, Hamm PS, Shaffer IN, et al. Differential thermotolerance adaptation between species of Coccidioides. J Fungi. 2020;6: 1-14. https://doi.org/10.3390/jof6040366 Identifying different thermotolerance levels between $C$. immitis and $C$. posadasii that may translate into their environmental niche.

56. Hamm PS, Hutchison MI, Leonard P, Melman S, Natvig DO. First analysis of human Coccidioides isolates from New Mexico and the Southwest Four Corners Region: implications for the distributions of C. posadasii and C. immitis and human groups at risk. J Fungi. 2019;5:74. https://doi.org/10.3390/jof5030074.

57. Johnson SM, Carlson EL, Fisher FS, Pappagianis D. Demonstration of Coccidioides immitis and Coccidioides posadasii DNA in soil samples collected from Dinosaur National Monument, Utah. Med Mycol. 2014;52:610-7. https:// doi.org/10.1093/mmy/myu004.

58. Kobziar LN, Thompson GR. Wildfire smoke, a potential infectious agent. Science (80- ). 2021;370:1408-10. https://doi.org/10. 1126/science.abe8116.

59. McCurdy SA, Portillo-Silva C, Sipan CL, Bang H, Emery KW. Risk for coccidioidomycosis among Hispanic farm workers, California, USA, 2018. Emerg Infect Dis. 2020;26:1430-7. https://doi.org/10.3201/eid2607.200024.

60. Schneider E. A Coccidioidomycosis outbreak following the Northridge, Calif, Earthquake. JAMA J Am Med Assoc. 1997;277:904-8. https://doi.org/10.1001/jama.1997. 03540350054033 .

61. Cooksey GLS, Wilken JA, McNary J, Gilliss D, Shusterman D, Materna BL, et al. Dust exposure and coccidioidomycosis prevention among solar power farm construction workers in California. Am J Public Health. 2017;107:1296-303. https://doi.org/10.2105/ AJPH.2017.303820.

62. Tong DQ, Wang JXL, Gill TE, Lei H, Wang B. Intensified dust storm activity and Valley fever infection in the southwestern United States. Geophys Res Lett. 2017;44:4304-12. https://doi. org/10.1002/2017GL073524.

63. Greene DR, Koenig G, Fisher MC, Taylor JW. Soil isolation and molecular identification of Coccidioides immitis. Mycologia. 2000;92:406-10. https://doi.org/10.1080/00275514.2000. 12061175 .

64. Barker BM, Tabor JA, Shubitz LF, Perrill R, Orbach MJ. Detection and phylogenetic analysis of Coccidioides posadasii in Arizona soil samples. Fungal Ecol. 2012;5:163-76. https:// doi.org/10.1016/j.funeco.2011.07.010.

65. De Macêdo RCL, Rosado AS, Da Mota FF, Cavalcante MAS, Eulálio KD, Filho AD, et al. Molecular identification of 
Coccidioides spp. in soil samples from Brazil. BMC Microbiol. 2011;11:108. https://doi.org/10.1186/1471-2180-11-108.

66. Bowers JR, Parise KL, Kelley EJ, Lemmer D, Schupp JM, Driebe EM, et al. Direct detection of Coccidioides from Arizona soils using CocciENV, a highly sensitive and specific real-time PCR assay. Med Mycol. 2019;57:246-55. https://doi.org/10.1093/ mmy/myy007.

67. Sheff KW, York ER, Driebe EM, Barker BM, Rounsley SD, Waddell VG, et al. Development of a rapid, cost-effective TaqMan real-time PCR assay for identification and differentiation of Coccidioides immitis and Coccidioides posadasii. Med Mycol. 2010;48:466-9. https://doi.org/10.3109/13693780903218990.

68. Engelthaler DM, Roe CC, Hepp CM, Teixeira M, Driebe EM, Schupp JM, et al. Local population structure and patterns of Western Hemisphere dispersal for Coccidioides spp., the fungal cause of valley fever. MBio. 2016;7:e00550-16. https://doi.org/ 10.1128/mBio.00550-16.

69. Oltean HN, Etienne KA, Roe CC, Gade L, McCotter OZ, Engelthaler DM, et al. Utility of whole-genome sequencing to ascertain locally acquired cases of coccidioidomycosis, Washington, USA. Emerg Infect Dis. 2019;25:501-6. https:// doi.org/10.3201/eid2503.181155.

70. Galgiani JN, Ampel NM, Blair JE, Catanzaro A, Geertsma F, Hoover SE, et al. 2016 Infectious Diseases Society of America (IDSA) clinical practice guideline for the treatment of coccidioidomycosis. Clin Infect Dis. 2016;63:e112-46. https://doi.org/10. 1093/cid/ciw360.

71. Teixeira MM, Alvarado P, Roe CC, et al. Population structure and genetic diversity among isolates of Coccidioides posadasii in Venezuela and surrounding regions. MBio. 2019;10(6):e0197619. https://doi.org/10.1128/mBio.01976-19.

72. Neafsey DE, Barker BM, Sharpton TJ, Stajich JE, Park DJ, Whiston E, et al. Population genomic sequencing of Coccidioides fungi reveals recent hybridization and transposon control. Genome Res. 2010;20:938-46. https://doi.org/10.1101/ gr.103911.109.

73. Whiston E, Zhang Wise H, Sharpton TJ, Jui G, Cole GT, Taylor JW. Comparative transcriptomics of the saprobic and parasitic growth phases in Coccidioides spp. PLoS One. 2012;7:e41034. https://doi.org/10.1371/journal.pone.0041034.

74. Friedman L, Smith CE, Pappagianis D, Berman RJ. Survival of Coccidioides immitis under controlled conditions of temperature and humidity. American Journal of Public Health and the Nations Health, 1956;46(10):1317-1324. https://doi.org/10.2105/ajph.46. 10.1317 .

75. Egeberg R, Elconin AE, Egeberg MC. Effect of salinity and temperature on Coccidioides immitis and three antagonistic soil saprophytes. J bacteriol. 1964;88(2):473-476. https://doi.org/10. 1128/jb.88.2.473-476.1964.

76. Fisher MC, Koenig GL, White TJ, Taylor JW. Molecular and phenotypic description of Coccidioides posadasii sp. nov., previously recognized as the non-California population of Coccidioides immitis. Mycologia. 2002;94:73-84.

77. Maddy KT. The geographic distribution of Coccidioides immitis and possible ecologic implications. Arizona Med. 1958;15(3): 178-188.

78. Gorris ME, Cat LA, Matlock M, Ogunseitan OA, Treseder KK, Randerson JT, et al. Coccidioidomycosis (Valley Fever) case data for the Southwestern United States. Open Health Data. 7:1. https:// doi.org/10.5334/ohd.31.

79. Mead HL, De Melo TM, Galgiani JN, Barker BM. Characterizing in vitro spherule morphogenesis of multiple strains of both species of Coccidioides. Med Mycol. 2019;57:478-88. https://doi.org/10. 1093/mmy/myy049.

80. Durkin M, Connolly P, Kuberski T, Myers R, Kubak BM, Bruckner D, et al. Diagnosis of coccidioidomycosis with use of the Coccidioides antigen enzyme immunoassay. Clin Infect Dis. 2008;47:e69-73. https://doi.org/10.1086/592073.

81. Narra HP, Shubitz LF, Mandel MA, Trinh HT, Griffin K, Buntzman AS, et al. A Coccidioides posadasii CPS1 deletion mutant is avirulent and protects mice from lethal infection. 2016;84:3007-16. https://doi.org/10.1128/IAI.00633-16.

82. Wise HZ, Hung C-Y, Whiston E, Taylor JW, Cole GT. Extracellular ammonia at sites of pulmonary infection with Coccidioides posadasii contributes to severity of the respiratory disease. Microb Pathog. 59-60:19-28. https://doi.org/10.1016/j. micpath.2013.04.003.

83. Xue J, Xia C, Dale S, Hung C-Y, Yu J-J, Cole GT. A genetically engineered live attenuated vaccine of Coccidioides posadasii protects BALB/c mice against coccidioidomycosis $\uparrow$. Infect Immun. 2009;77:3196-208. https://doi.org/10.1128/IAI.00459-09.

84. Hung C-Y, Seshan KR, Yu J-J, Schaller R, Xue J, Basrur V, et al. A metalloproteinase of Coccidioides posadasii contributes to evasion of host detection. Infect Immun. 2005;73:6689-703. https:// doi.org/10.1128/IAI.73.10.6689-6703.2005.

85. Kellner EM, Orsborn KI, Siegel EM, Mandel MA, Orbach MJ, Galgiani JN. Coccidioides posadasii contains a single 1,3-betaglucan synthase gene that appears to be essential for growth. Eukaryot Cell. 2005;4:111-20. https://doi.org/10.1128/EC.4.1. 111-120.2005.

86. Hung C-Y, Yu J-J, Seshan KR, Reichard U, Cole GT. A parasitic phase-specific adhesin of Coccidioides immitis contributes to the virulence of this respiratory Fungal pathogen. Infect Immun. 2002;70:3443-56. https://doi.org/10.1128/iai.70.7.3443-3456. 2002.

87. Abuodeh RO, Orbach MJ, Mandel MA, Das A, Galgiani JN. Genetic transformation of Coccidioides immitis facilitated by Agrobacterium tumefaciens. J Infect Dis. 2000;181:2106-10. https://doi.org/10.1086/315525.

88. Mirbod-Donovan F, Schaller R, Hung C-Y, Xue J, Reichard U, Cole GT. Urease produced by Coccidioides posadasii contributes to the virulence of this respiratory pathogen. Infect Immun. 2006;74:504-15. https://doi.org/10.1128/IAI.74.1.504-515.2006.

89. Mead HL, Roe CC, Higgins Keppler EA, Van Dyke MCC, Laux $\mathrm{KL}$, Funke AL, et al. Defining critical genes during spherule remodeling and endospore development in the fungal pathogen, Coccidioides posadasii. Front Genet. 2020;11. https://doi.org/10. 3389/fgene.2020.00483.

90. Lewis ERG, David VR, Doyle AL, Rajabi K, Kiefer JA, Pirrotte $\mathrm{P}$, et al. Differences in host innate responses among Coccidioides isolates in a murine model of pulmonary coccidioidomycosis. 2015;14:1043-53. https://doi.org/10.1128/EC.00122-15.

91. Hung C-Y, Wise HZ, Cole GT. Gene disruption in Coccidioides using hygromycin or phleomycin resistance markers. Methods Mol Biol. 2012;845:131-47. https://doi.org/10.1007/978-161779-539-8 9.

92. Cole GT, Sun SH. Arthroconidium-spherule-endospore transformation in Coccidioides immitis. In: Fungal Dimorphism: Springer US; 1985. p. 281-333. https://doi.org/10.1007/978-1-4684-49822_12.

93. Boeke JD, LaCroute F, Fink GR. A positive selection for mutants lacking orotidine-5' -phosphate decarboxylase activity in yeast: 5fluoro-orotic acid resistance. Mol Gen Genet. 1984;197:345-6. https://doi.org/10.1007/BF00330984.

94. Morio F, Lombardi L, Butler G. The CRISPR toolbox in medical mycology: state of the art and perspectives. PLoS Pathog. 2020;16:e1008201. https://doi.org/10.1371/journal.ppat.1008201.

95. Van Dyke MCC, Thompson GR, Galgiani JN, Barker BM. The rise of Coccidioides: forces against the dust devil unleashed. Front Immunol. 2019. https://doi.org/10.3389/fimmu.2019.02188 A recent, comprehensive review of coccidioidomycosis therapeutics, host response, and vaccine development. 
96. Cox RA, Magee DM. Coccidioidomycosis: host response and vaccine development. Clin Microbiol Rev table of contents. 2004;17:804-39. https://doi.org/10.1128/CMR.17.4.804-839. 2004.

97. Castro-Lopez N, Hung C-Y. Immune response to coccidioidomycosis and the development of a vaccine. Microorganisms. 2017;5. https://doi.org/10.3390/microorganisms5010013.

98. Hung C-Y, Hsu AP, Holland SM, Fierer J. A review of innate and adaptive immunity to coccidioidomycosis. Med Mycol. 2019;57: S85-92. https://doi.org/10.1093/mmy/myy146.

99. Diep AL, Hoyer KK. Host response to Coccidioides infection: fungal immunity. Front Cell Infect Microbiol. 2020;10:581101. https://doi.org/10.3389/fcimb.2020.581101 A recent, comprehensive review on the host response to Coccidioides infection.

100. Hung C-Y, Gonzalez A, Wüthrich M, Klein BS, Cole GT. Vaccine immunity to coccidioidomycosis occurs by early activation of three signal pathways of T helper cell response (Th1, Th2, and Th17). Infect Immun. 2011;79:4511-22. https://doi.org/10.1128/IAI. 05726-11.

101. Hung C-Y, del Pilar Jiménez M, Gonzalez A, Wüthrich M, Klein BS, Cole GT. Interleukin-1 receptor but not Toll-like receptor 2 is essential for MyD88-dependent Th17 immunity to Coccidioides infection. Infect Immun. 2014;82:2106-14. https://doi.org/10. 1128/IAI.01579-13.

102. Slagle DC, Cox RA, Kuruganti U. Induction of tumor necrosis factor alpha by spherules of Coccidioides immitis. Infect Immun. 1989;57:1916-21. https://doi.org/10.1128/IAI.57.7.1916-1921. 1989.

103. Viriyakosol S, del Pilar Jiménez M, Gurney MA, Ashbaugh ME, Fierer J. Dectin-1 is required for resistance to coccidioidomycosis in mice. MBio. 2013;4:e00597-12. https://doi.org/10.1128/mBio. 00597-12.

104. Viriyakosol S, Fierer J, Brown GD, Kirkland TN. Innate immunity to the pathogenic fungus Coccidioides posadasii is dependent on Toll-like receptor 2 and Dectin-1. Infect Immun. 2005;73:155360. https://doi.org/10.1128/IAI.73.3.1553-1560.2005.

105. Chariot P, Monnet I, LeLong F, Chleq C, Droz JP, de Cremoux H. Systemic mast cell disease associated with primary mediastinal germ cell tumor. Am J Med. 1991;90:381-5.

106. Campuzano A, Zhang H, Ostroff GR, dos Santos DL, Wüthrich M, Klein BS, et al. CARD9-associated Dectin-1 and Dectin-2 are required for protective immunity of a multivalent vaccine against Coccidioides posadasii infection. J Immunol. 2020;204:3296306. https://doi.org/10.4049/jimmunol.1900793 Further investigation on the GCP-rCpa1 vaccine which demonstrates a protective Th17 response through activation of CARD-9 associated signaling pathways Dectin-1 and Dectin-2.

107. Cole GT, Hurtgen BJ, Hung C-Y. Progress toward a human vaccine against coccidioidomycosis. Curr Fungal Infect Rep. 2012;6: 235-44. https://doi.org/10.1007/s12281-012-0105-y.

108. Xue J, Hung C-Y, Yu J-J, Cole GT. Immune response of vaccinated and non-vaccinated mice to Coccidioides posadasii infection. Vaccine. 2005;23:3535-44. https://doi.org/10.1016/j. vaccine.2005.01.147.

109. Hung C-Y, Castro-Lopez N, Cole GT. Card9- and MyD88mediated gamma interferon and nitric oxide production is essential for resistance to subcutaneous Coccidioides posadasii infection. Infect Immun. 2016;84:1166-75. https://doi.org/10.1128/ IAI.01066-15.

110. Edwards JE, Schwartz MM, Schmidt CS, et al. A fungal immunotherapeutic vaccine (NDV-3A) for treatment of recurrent vulvovaginal candidiasis - a phase 2 randomized, double-blind, placebo-controlled trial. Clin Infect Dis. 2018;66:1928-36. https://doi.org/10.1093/cid/ciy185.
111. Alqarihi A, Singh S, Edwards JE, Ibrahim AS, Uppuluri P. NDV3 A vaccination prevents $C$. albicans colonization of jugular vein catheters in mice. Sci Rep. 2019;9:1-6. https://doi.org/10.1038/ s41598-019-42517-y.

112. Singh S, Uppuluri P, Mamouei Z, Alqarihi A, Elhassan H, French $\mathrm{S}$, et al. The NDV-3A vaccine protects mice from multidrug resistant Candida auris infection. PLoS Pathog. 2019;15:e1007460. https://doi.org/10.1371/journal.ppat.1007460.

113. Levine MM, Sztein MB. Vaccine development strategies for improving immunization: the role of modern immunology. Nat Immunol. 2004;5:460-4. https://doi.org/10.1038/ ni0504-460.

114. Hung C-Y, Castro-Lopez N, Cole GT. Vaccinated C57BL/6 Mice develop protective and memory $\mathrm{T}$ cell responses to Coccidioides posadasii infection in the absence of interleukin-10. 2014;82:90313. https://doi.org/10.1128/IAI.01148-13.

115. Shubitz LF, Powell DA, Trinh HT, Lewis ML, Orbach MJ, Frelinger JA, et al. Viable spores of Coccidioides posadasii $\Delta \mathrm{cps} 1$ are required for vaccination and provide long lasting immunity. Vaccine. 2018;36:3375-80. https://doi.org/10.1016/j. vaccine.2018.04.026.

116. Shubitz LF, Bowen R, Robb EJ, Powell DA, Bosco-Lauth A, Hartwig A, et al. 1732. A canine target species challenge model to evaluate efficacy of a Coccidioidomycosis vaccine. Open Forum Infect Dis. 2019;6:S634-5. https://doi.org/10.1093/ofid/ ofz360.1595.

117. Tarcha EJ, Basrur V, Hung C-Y, Gardner MJ, Cole GT. Multivalent recombinant protein vaccine against coccidioidomycosis. Infect Immun. 2006;74:5802-13. https://doi.org/10.1128/ IAI.00961-06.

118. Jiang C, Magee DM, Ivey FD, Cox RA. Role of signal sequence in vaccine-induced protection against experimental coccidioidomycosis. Infect Immun. 2002;70:3539-45. https://doi.org/10.1128/IAI.70.7. 3539-3545.2002.

119. Jiang C, Magee DM, Quitugua TN, Cox RA. Genetic vaccination against Coccidioides immitis: comparison of vaccine efficacy of recombinant antigen 2 and antigen 2 cDNA. Infection and Immunity. 1999;67(2):630-635. https://doi.org/10.1128/IAI.67. 2.630-635.1999.

120. Herr RA, Chiung-Yu H, Cole GT. Evaluation of two homologous proline-rich proteins of Coccidioides posadasii as candidate vaccines against coccidioidomycosis. Infect Immun. 2007;75:577787. https://doi.org/10.1128/IAI.00807-07.

121. Santoro D, Susan R, Ribeiro P, Cunha-Neto E, Hirszfeld ÓL. CD4 $+\mathrm{T}$ cell epitope discovery and rational vaccine design. 2010 . https://doi.org/10.1007/s00005-010-0067-0.

122. Hurtgen BJ, Hung C-Y, Ostroff GR, Levitz SM, Cole GT. Construction and evaluation of a novel recombinant $\mathrm{T}$ cell epitope-based vaccine against coccidioidomycosis. 2012;80; 3960-74. https://doi.org/10.1128/IAI.00566-12.

123. Orsborn KI, Shubitz LF, Peng T, Kellner EM, Orbach MJ, Haynes PA, et al. Protein expression profiling of Coccidioides posadasii by two-dimensional differential in-gel electrophoresis and evaluation of a newly recognized peroxisomal matrix protein as a recombinant vaccine candidate. Infect Immun. 2006;74:1865-72. https://doi.org/10.1128/IAI.74.3.1865-1872.2006.

124. Tarcha EJ, Basrur V, Hung C-Y, Gardner MJ, Cole GT. A recombinant aspartyl protease of Coccidioides posadasii induces protection against pulmonary coccidioidomycosis in mice. Infect Immun. 2006;74:516-27. https://doi.org/10.1128/IAI.74.1.516527.2006.

125. Hayden CA, Hung CY, Zhang H, Negron A, Esquerra R, Ostroff $\mathrm{G}$, et al. Maize-produced $\mathrm{Ag} 2$ as a subunit vaccine for valley fever. J Infect Dis. 2020;221:615-23. https://doi.org/10.1093/infdis/ jiz196. 
126. Shubitz LF, Yu JJ, Hung CY, Kirkland TN, Peng T, Perrill R, et al. Improved protection of mice against lethal respiratory infection with Coccidioides posadasii using two recombinant antigens expressed as a single protein. Vaccine. 2006;24:5904-11. https:// doi.org/10.1016/j.vaccine.2006.04.002.

127. Hung C-Y, Zhang H, Castro-Lopez N, et al. Glucan-chitin particles enhance Th17 response and improve protective efficacy of a multivalent antigen (rCpa1) against pulmonary Coccidioides posadasii. Infection. 2018. https://doi.org/10.1128/IAI.
128. Teixeira MM, Barker BM, Stajich JE. Improved reference genome sequence of Coccidioides immitis Strain WA 211, isolated in Washington State. 2019 https://doi.org/10.1128/MRA.00149-19

129. Mitchell NM, Sherrard AL, Dasari S, Magee DM, Grys TE, Lake DF. Proteogenomic re-annotation of Coccidioides posadasii Strain Silveira. Proteomics. 2018;18:1700173. https://doi.org/10. 1002/pmic.201700173.

Publisher's Note Springer Nature remains neutral with regard to jurisdictional claims in published maps and institutional affiliations. 